\title{
Evaluation of machining content and labor intensity of manufacturing products of new nomenclature when determining the cost of fulfilling an order at highly specialized machine- building enterprises
}

\author{
Sergey N. Grigoriev ${ }^{1}$, Vitaliy A. Dolgov ${ }^{2, *}$, Pavel I. Umnov ${ }^{3}$, Nikolay N . Fokin ${ }^{3}$, and Olga \\ $S$. Proshkina ${ }^{4}$ \\ ${ }^{1}$ MSUT «STANKIN», Moscow, Russia \\ ${ }^{2}$ LLC "Digital Systems Factory", Moscow, Russia \\ ${ }^{3} \mathrm{PJSC}$ «DSPP», Dolgprudny, Russia \\ ${ }^{4} \mathrm{PJSC}$ «NPO «Almaz» Moscow, Russia
}

\begin{abstract}
The problem of operational calculation of machining content and labor intensity of manufacturing parts of a new nomenclature, mainly processed by cutting, at highly specialized machine-building enterprises when calculating the technical and economic indicators of the order is considered. The proposed estimation algorithm is based on the operational calculation of the machining content of cutting operations and the calculation of the reduced labor intensity of heat treatment operations, electroplating and lacquer coating, as well as locksmith and control operations.
\end{abstract}

\section{Introduction}

The modern market of machine-building products imposes strict requirements to reduce labor intensity, cost and production time.

This is especially true for machine-building enterprises that specialize in the production of permanent products for a narrow market segment. In an unstable market, the demand for products intended for a narrow market segment is subject to changes, which leads to the need to diversify products [1-3].

Therefore, companies that have a narrow specialization should form mechanisms for rapid calculation of technical and economic indicators for the implementation of a prospective order and, in the future, technological preparation for its implementation.

At the moment, such enterprises do not have the appropriate tools. Due to the existing features, enterprises do not have methodological, mathematical and software types for calculating the technical and economic indicators of manufacturing products of the new

\footnotetext{
* Corresponding author: dolgov@digitalfabrika.ru
} 
nomenclature. This leads to significant labor intensity and inability to respond quickly to the demands of the machine-building products market [4-6].

For enterprises with a narrow specialization, it is typical to produce products of a relatively stable nomenclature over a long period of time. As a rule, new products are modifications of the traditional product range.

Calculation of technical and economic indicators for manufacturing a specific product modification is carried out by comparing the design and technological parameters of the product modification with the corresponding parameters of the manufactured product.

It is also worth noting that the development of structural and technological parameters of a new product modification is carried out over a long period of time - several years.

When calculating the technical and economic indicators of manufacturing a product of a new nomenclature, existing methods are not acceptable, because they can not provide either the accuracy of the calculation or the required time.

Therefore, the development of a tool for rapid assessment of technical and economic parameters of manufacturing products of a new nomenclature for highly specialized enterprises is an urgent task, the solution of which is necessary for rapid response to the demands of the machine-building products market.

Technological appearance of a machine-building enterprise with a narrow specialization

In the production system of the machine-building enterprise under consideration, it is possible to distinguish technologically oriented and subject-closed production divisions.

Table 1 provides a description of the features of the considered production divisions from the perspective of their use in the diversification of machine-building products.

Table 1. Features of production shops

\begin{tabular}{|l|l|}
\hline Subject-closed production shops & Technologically oriented production units \\
\hline Highly specialized jobs. & Low specialization of jobs. \\
\hline $\begin{array}{l}\text { Readjustment is difficult and rarely } \\
\text { performed. }\end{array}$ & $\begin{array}{l}\text { The readjustment of the model, performed } \\
\text { periodically. }\end{array}$ \\
\hline Readjustment is performed in a narrow range. & Readjustment is performed in a wide range. \\
\hline $\begin{array}{l}\text { The special and specialized equipment } \\
\text { prevail. }\end{array}$ & $\begin{array}{l}\text { Universal technological equipment and equipment } \\
\text { prevail. }\end{array}$ \\
\hline $\begin{array}{l}\text { The equipment is located in the technological } \\
\text { sequence of manufacturing products. }\end{array}$ & $\begin{array}{l}\text { The location of the equipment does not take into } \\
\text { account the technological sequence of } \\
\text { manufacturing products. }\end{array}$ \\
\hline $\begin{array}{l}\text { The technical capabilities of the equipment } \\
\text { are designed to implement certain } \\
\text { technological processes. }\end{array}$ & $\begin{array}{l}\text { The technical capabilities of the equipment are } \\
\text { designed to implement a large number of } \\
\text { technological processes. }\end{array}$ \\
\hline Highly specialized small-scale production & Multi-product production \\
\hline
\end{tabular}

Thus, in the production system of a highly specialized machine-building enterprise, it is possible to distinguish multi-nomenclature and low-nomenclature production divisions.

Figure 1 shows the typical distribution of technological processing related to technologically oriented and subject-closed production divisions. 


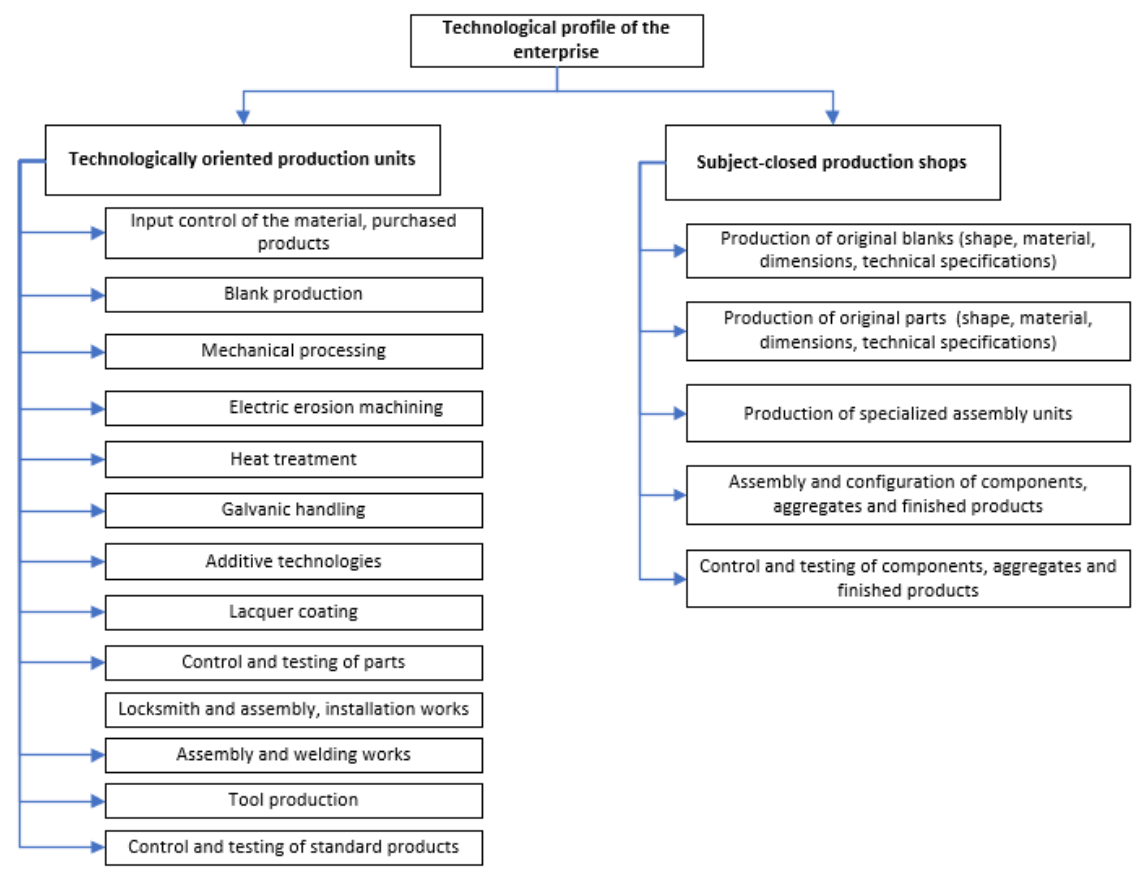

Fig. 1. Technological profile of a typical highly specialized enterprise.

Based on the analysis of characteristics of production units (see table 1) we can draw the following conclusions:

- subject closed production units are specialized and their use for the manufacture of products a new range is causing significant organizational and technological complexity,

- technology-oriented production units are the basis for production of new items.

\section{The production profile of products}

The primary task in assessing the technical and economic indicators of manufacturing products of the new nomenclature is to analyze the compliance of the existing technical capabilities of the enterprise with the technologically necessary requirements.

As a result of this assessment, a list of components is formed that it is advisable to produce with the involvement of external cooperation.

It also determines the technological types of processing that it is advisable to produce with the involvement of external cooperation.

Thus, the production appearance of the product of the new nomenclature is formed (Figure 2), taking into account the production and technological capabilities of a particular enterprise. 


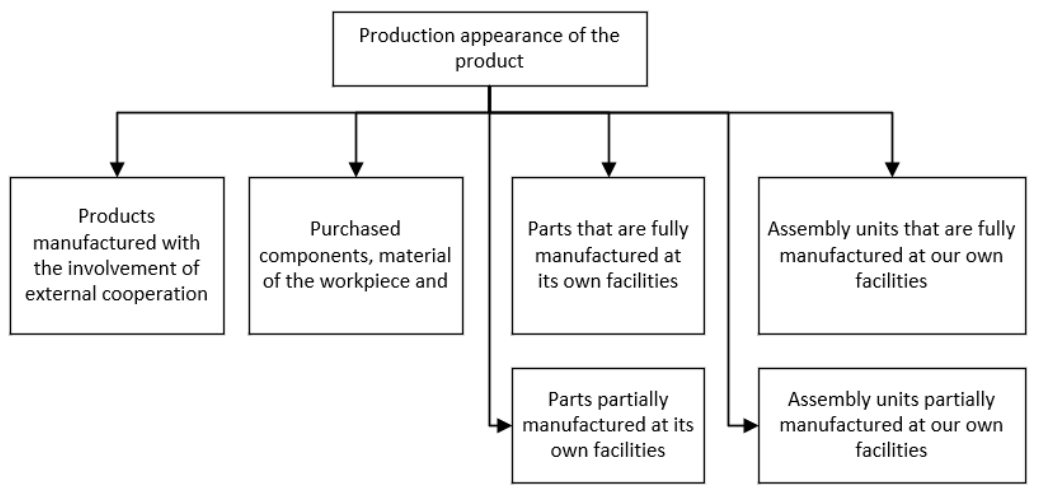

Fig. 2. Production appearance of the product.

Different approaches are required to determine the technical and economic indicators of manufacturing and technological preparation of production for each group of products that form the production appearance of the product (Table 2).

Table 2. Description of groups of components that make up the product's production appearance

\begin{tabular}{|c|c|c|}
\hline Name & Description & $\begin{array}{c}\text { Features of technological preparation of } \\
\text { production }\end{array}$ \\
\hline $\begin{array}{l}\text { Parts that are fully } \\
\text { manufactured at our } \\
\text { own facilities }\end{array}$ & $\begin{array}{l}\text { Manufacturing of parts is } \\
\text { completely performed by } \\
\text { our own resources. }\end{array}$ & \multirow{2}{*}{$\begin{array}{l}\text { Providing additional technological } \\
\text { capabilities of production units or } \\
\text { increasing productivity requires the } \\
\text { purchase of expensive technological } \\
\text { equipment, as well as the training of } \\
\text { appropriate specialists. } \\
\text { Within the framework of a single order, } \\
\text { significant investments will not pay off. } \\
\text { A large number of item items for parts. } \\
\text { Technological processes for manufacturing } \\
\text { parts in multi-product production are } \\
\text { characterized by a low concentration of } \\
\text { transitions and contain a large number of } \\
\text { operations. }\end{array}$} \\
\hline $\begin{array}{l}\text { Parts partially } \\
\text { manufactured at our } \\
\text { own facilities }\end{array}$ & $\begin{array}{l}\text { The main processing of } \\
\text { workpieces is carried out by } \\
\text { the company's resources. } \\
\text { Certain types of processing } \\
\text { are performed with the } \\
\text { involvement of external } \\
\text { cooperation (electroplating, } \\
\text { thermal processing, } \\
\text { formation of complex } \\
\text { precise surfaces, etc.). }\end{array}$ & \\
\hline $\begin{array}{l}\text { Assembly units that } \\
\text { are fully } \\
\text { manufactured at our } \\
\text { own facilities }\end{array}$ & $\begin{array}{l}\text { Production of Assembly } \\
\text { units is completely } \\
\text { performed by our own } \\
\text { resources. }\end{array}$ & \multirow{2}{*}{$\begin{array}{l}\text { Providing additional technological } \\
\text { capabilities of production units or } \\
\text { increasing productivity can be achieved by } \\
\text { purchasing Assembly equipment and } \\
\text { training appropriate specialists, which } \\
\text { requires less investment. } \\
\text { Special control and testing equipment can } \\
\text { be a significant expense. } \\
\text { A small number of item items for } \\
\text { Assembly units. } \\
\text { Assembly processes in multi-product } \\
\text { production are characterized by a high } \\
\text { concentration of transitions, low } \\
\text { specialization, and contain a small number } \\
\text { of operations. }\end{array}$} \\
\hline $\begin{array}{l}\text { Assembly units that } \\
\text { are monitored and } \\
\text { tested with the } \\
\text { involvement of } \\
\text { external cooperation }\end{array}$ & $\begin{array}{l}\text { The main part of the work } \\
\text { includes: locksmith and } \\
\text { Assembly, electrical } \\
\text { installation and Assembly } \\
\text { and welding work. } \\
\text { Control and testing of } \\
\text { Assembly units are carried } \\
\text { out with the involvement of } \\
\text { external cooperation. }\end{array}$ & \\
\hline
\end{tabular}


Thus, the processes of manufacturing parts that are part of the product of the new nomenclature, to a greater extent, require analysis of their own resources.

\section{Algorithm for calculating the labor intensity of manufacturing products of the new nomenclature}

The basis for calculating technical and economic parameters is the machining content and labor intensity of each type of processing.

When analyzing the machining content and labor intensity of the product of the new nomenclature, technological processes for manufacturing parts and Assembly units are distinguished.

The technological processes of manufacturing parts are more estimated by the machining content, and the technological processes of Assembly-by the labor intensity.

Resource planning to ensure the machining content of manufacturing a new product range requires more detailed study $[6,7,8,9]$.

Currently, there are a significant number of methods for calculating the machining content and labor intensity of manufacturing parts using computer-aided design of technological processes $[10,11,12,13]$.

The analysis made it possible to identify the main principles used in the calculations, which are discussed in table 3.

Table 3. Basic principles of calculating the labor intensity and machining content of manufacturing parts when determining the technical and economic indicators of manufacturing products of the new nomenclature.

\begin{tabular}{|c|c|c|}
\hline Principle & Description & $\begin{array}{l}\text { Advantages and } \\
\text { disadvantages }\end{array}$ \\
\hline $\begin{array}{l}\text { Calculation based } \\
\text { on the reduced } \\
\text { machining } \\
\text { content and labor } \\
\text { intensity }\end{array}$ & $\begin{array}{l}\text { An information model is developed for each part of the } \\
\text { specified item. } \\
\text { Details are grouped according to certain characteristics. } \\
\text { A representative item in each group is highlighted. } \\
\text { The technological process of manufacturing a } \\
\text { representative part is developed and the machining } \\
\text { content and labor intensity of each operation are } \\
\text { calculated. } \\
\text { All group details borrow the process structure of the } \\
\text { representative part. } \\
\text { The coefficients of bringing each part in the group to the } \\
\text { representative part are calculated. } \\
\text { The values of machining content and labor intensity of } \\
\text { each part manufacturing operation in the group are } \\
\text { calculated. }\end{array}$ & $\begin{array}{l}\text { Minor labor } \\
\text { intensity of the } \\
\text { calculation. } \\
\text { The low accuracy } \\
\text { of the cast. }\end{array}$ \\
\hline $\begin{array}{l}\text { Calculation of } \\
\text { labor intensity } \\
\text { using CAM } \\
\text { systems }\end{array}$ & $\begin{array}{l}\text { Develop 3D models of all parts of the specified range. } \\
\text { Details are grouped according to certain characteristics. } \\
\text { A representative item in each group is highlighted. } \\
\text { The structure of the technological process of } \\
\text { manufacturing a representative part is being developed. } \\
\text { Part processing projects are developed for each } \\
\text { operation. }\end{array}$ & 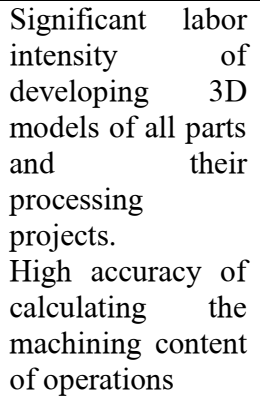 \\
\hline
\end{tabular}


In the proposed method of calculation of the labor intensity and machining content the manufacture of parts identifies the following types of transactions:

activity, characterized by low machining content with expensive equipment: CNC machines, coordinate measuring machines, etc.,

operation, characterized by high machining content and low labor intensity: heattreatment, electroplating processing, drying, etc.

- transactions characterized by high complexity: metal, control, etc.

Calculating the machining content of operations performed on expensive equipment requires accurate calculation [14-17].

When calculating the machining content and labor intensity of the other two types of accuracy can be neglected in the interests of reducing the calculation time.

Therefore, to calculate the machining content of manufacturing a given range of parts, a method based on analytical calculation of the duration of typical cycles of processing parts on $\mathrm{CNC}$ machines is proposed: turning, milling and milling machines.

Calculation of machining content and labor-intensive operations of heat treatment, electroplating and lacquer coating, as well as locksmith and control operations, is based on the use of reduction coefficients.

The algorithm for calculating the machining content and labor intensity of processing parts of the new product range is shown in Figure 3.

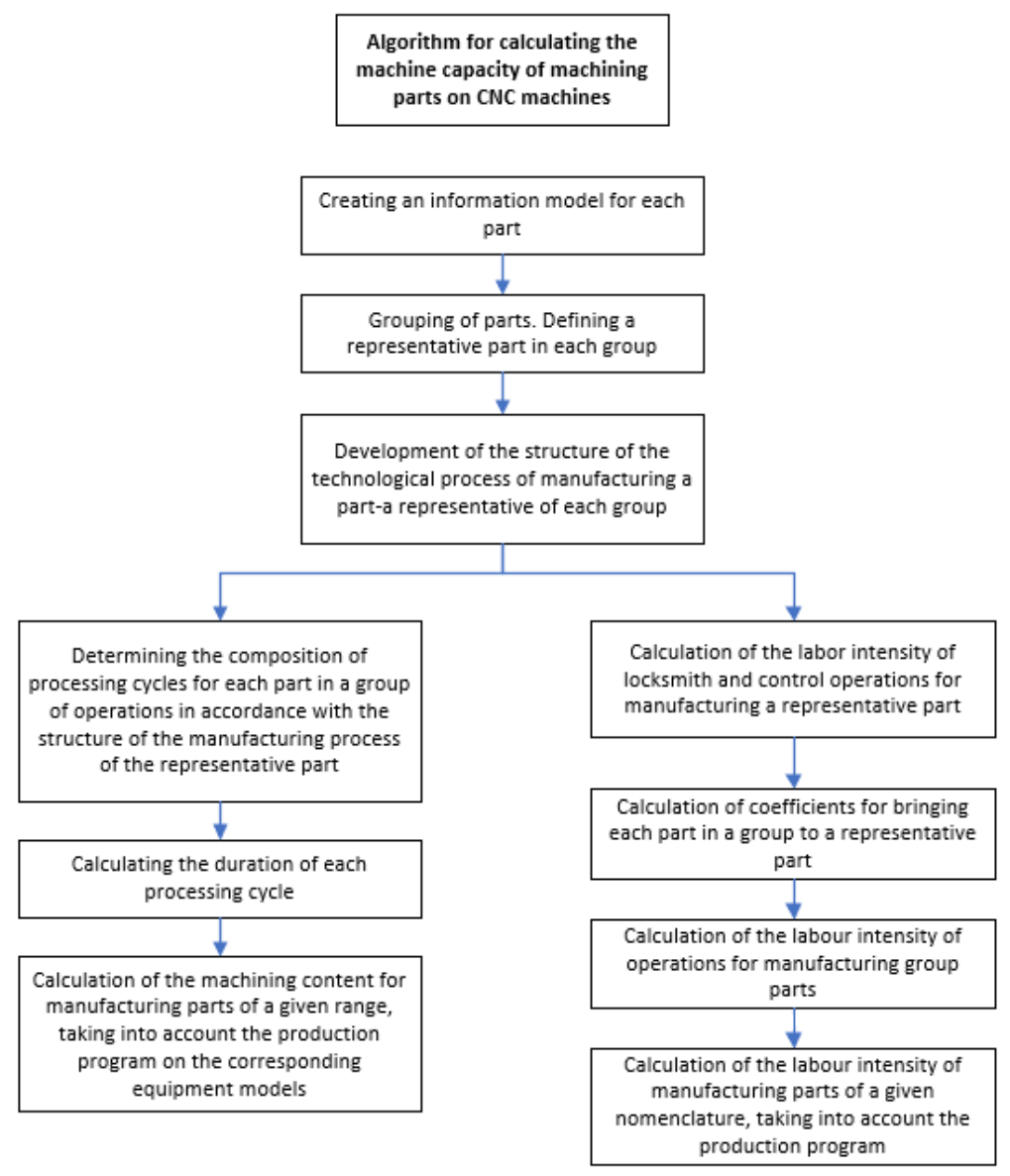

Fig. 3. Algorithm for calculating the machining content and labor intensity of processing parts of the new nomenclature. 


\section{Conclusions}

It is shown that to diversify the product range, the production base of a highly specialized enterprise consists of technologically oriented production units.

The proposed estimation algorithm is based on the operational calculation of the machining content of cutting operations and the calculation of the reduced labor intensity of heat treatment operations, electroplating and lacquer coating, as well as locksmith and control operations.

The proposed algorithm takes into account limitations and assumptions when calculating the machining content and labor intensity of manufacturing parts of a new range to determine the technical and economic parameters of order fulfillment.

This research was funded by Ministry of Science and Higher Education of the Russian Federation, Grant No. 0707-2020-0025.

\section{References}

1. S.N. Grigoriev, G.M. Martinov, Scalable open cross-platform kernel of PCNC system for multi-axis machine tool, Procedia CIRP, 1(1), c. 238-243 (2012)

2. V.A. Dolgov, E.G. Rakhmilevich V.Yu. Pyatnov, A.A. Podkidishev, Product development for manufacturability in the diversification of defense industry machine-building enterprises in the context of the development of digital production, Vestnik MSUT “STANKIN”, №4(47). C. 8-12, (2018)

3. S.N. Grigoriev, D.A. Masterenko, V.I. Teleshevskii, P.N. Emelyanov, Contemporary state and outlook for development of metrological assurance in the machine-building industry, Measurement Techniques, 55(11), pp. 13111315, (2013)

4. I. A. Kovalev, P. A. Nikishechkin and A. S. Grigoriev. Approach to programmable controller building by its main modules synthesizing based on requirements specification for industrial automation, International Conference on Industrial Engineering, Applications and Manufacturing (ICIEAM), St. Petersburg, pp.1-4 (2017)

5. A. A. Kutin, V. A. Dolgov, A. A. Kabanov, et al, Competitive-resource information model of the machine building manufacturing system, IOP Conference Series-Materials Science and Engineering, Vol. 448, No. UNSP 012008, 2018. 23rd International Conference on Manufacturing (John Neumann Univ, GAMF Fac Campus, Kecskemet, Hungary) (2018)

6. A.A. Kutin, V.A. Dolgov, A.A. Podkidyshev, A.A. Kabanov, Simulation Modeling of Assembly Processes in Digital Manufacturing, Procedia CIRP. 11. Cep. "11th CIRP Conference on Intelligent Computation in Manufacturing Engineering, CIRP ICME 2017", pp. 470-475 (2017)

7. S.N. Grigoriev, G.M. Martinov, An ARM-based Multi-channel CNC Solution for Multi-tasking Turning and Milling Machines. Procedia CIRP, 46, c. 525-528, (2016)

8. N. M. Bobrovskij, P. A. Melnikov, S. N. Grigoriev, I. N. Bobrovskij, Simulation of thermal fields using different types of wide burnishing, IOP Conf. Ser.: Mater. 
Sci. Eng. 91012034 (2015)

9. I.A. Kovalev, M.S. Babin, P.A. Nikishechkin. Development of a method for the determination and registration of unauthorized data transmission channels at industrial manufactories, MATEC Web of Conferences (Vol. 298, p. 00110). EDP Sciences (2019)

10. P.A. Nikishechkin, N.S. Grigoriev, N.Yu. Chervonnova, Construction of a specialized control system for brush machine and rounding the cutting edges of a metal cutting tool, In MATEC Web of Conferences (Vol. 298, p. 00064). EDP Sciences (2019)

11. M.A. Volosova, S.N. Grigor'ev, \& V.V. Kuzin, Effect of Titanium Nitride Coating on Stress Structural Inhomogeneity in Oxide-Carbide Ceramic. Part 4. Action of Heat Flow. Refract Ind Ceram 56, 91-96 (2015)

12. V.V. Kuzin, S.N. Grigoriev, M.Yu. Fedorov, Role of the thermal factor in the wear mechanism of ceramic tools. Part 2: Microlevel, J. Frict. Wear. 36(1), pp. 40-44 (2015)

13. V.V. Kuzin, S.N. Grigor'ev, M.A. Volosova, Effect of a TiC Coating on the Stress-Strain State of a Plate of a High-Density Nitride Ceramic Under Nonsteady Thermoelastic Conditions, Refract. Ind. Ceram. 54, pp. 376-380 (2014)

14. S.N. Grigoriev, G.M. Martinov, The Control Platform for Decomposition and Synthesis of Specialized CNC Systems, Proc. CIRP 41, pp. 858-863 (2016)

15. S.N. Grigoriev, G.M. Martinov, Research and development of a cross-platform CNC kernel for multi-axis machine tool, Proc. CIRP 14, pp. 517-522 (2014)

16. L.I. Martinova, N.N. Fokin, An approach to creation of a unified system of programming CNC machines in the dialog mode, MATEC Web Conf. Volume 224, 2018. International Conference on Modern Trends in Manufacturing Technologies and Equipment (ICMTMTE 2018). Sevastopol, Russia, September 10-14, pp.1-5, (2018)

17. L. I. Martinova, R. L. Pushkov, N. N. Fokin, Development of standardized tools for shopfloor programming of turning and turn-milling machines, IOP Conference Series: Materials Science and Engineering (Vol. 709, No. 4, p. 044064). IOP Publishing, (2020) 